\title{
DOES IFRS CONVERGENCE PROMOTE THE VALUE RELEVANCE OF ACCOUNTING INFORMATION?
}

\author{
Ari Budi Kristanto \\ Fakultas Ekonomika dan Bisnis, Universitas Kristen Satya Wacana \\ ari.kristanto@staff.uksw.edu
}

\begin{abstract}
ABSTRAK
Penelitian ini bertujuan untuk memperoleh bukti empiris mengenai adanya kandungan informasi, relevansi nilai informasi akuntansi dan pertumbuhannya selama proses konvergensi IFRS di Indonesia. Secara khusus penelitian ini dilakukan pada perusahaan perbankan, asuransi dan pembiayaan yang terdaftar di Bursa Efek Indonesia. Kandungan informasi diindikasikan oleh Trading Volume Activity dan Variability of Abnormal Return. Adapun relevansi nilai informasi akuntansi diproksikan oleh koefisien regresi dari fungsi pengaruh informasi akuntansi terhadap harga saham. Hasil penelitian ini menemukan adanya kandungan informasi serta relevansi nilai informasi akuntansi selama periode konvergensi IFRS. Temuan empiris ini menjadi salah satu indikasi adanya manfaat konvergensi IFRS bagi relevansi nilai informasi akuntansi. Berkaitan dengan konvergensi itu sendiri, penelitian ini menemukan bahwa relevansi nilai informasi akuntansi mengalami peningkatan secara bertahap selama periode konvergensi. Relevansi nilai informasi akuntansi ditemukan pada perusahaan dengan rasio saham diperdagangkan yang tinggi serta perusahaan dengan saham yang tidak likuid. Relevansi nilai yang lebih tinggi juga ditemukan pada perusahaan yang terafiliasi dengan perusahaan dari negara yang mengadopsi IFRS.
\end{abstract}

Kata kunci: kandungan informasi, relevansi nilai, IFRS

\section{INTRODUCTION}

Accounting as the market's main information sources, should be built on effective, transparent, and relevant standard, so that various stakeholders could understand the provided report. In regard to business internationalization, which allows corporates to obtain the worldwide fundings, the international stakeholders' understanding of financial reporting is an absolute requirement. Then, IFRS is claimed as the answer to that needs, as it is designated to be principle base standard, which is produced clear and transparent information.

Recently, the IFRS implementation as the financial reporting standard has been spread to many countries. Over 120 contries require the public companies to 
adopt IFRS as their reporting standard (ifrs.com, 2015). International effort to converge the IFRS is being supported by the financial ministers of G20 countries.

Indonesia local accounting standards (PSAK) have been gradually conformed to IFRS principles. It is the process of IFRS convergence into local standard (PSAK as the local GAAP), instead of adoption. The convergence was conducted by gradual elimination of differences between local standard and IFRS. It is expected that the Indonesian public firm's financial reporting is conform to the IFRS.

The convergence is being conducted to improve the quality and the functionality of financial reporting practice. The implementation of converged local standard is expected to promote the financial report's comparability and quality, provide qualified information to international stakeholder, and reduce the barrier of international capital flow. Ramanna and Sletten (2009) found that the IFRS adoption by 102 countries outside EU is motivated by the fact that their businesss partners are IFRS adopters. The survey conducted by IFAC (International Federation of Accounting) found that 90 percent of accounting managers from various countries are encouraging a single set of worldwide accounting standard as the critical component to economic growth (AICPA 2011).

Studies concerning the usefulness of IFRS adoption have been carried out, which finds the increasing of information accuration in forecasting purposes (Horton et al., 2010), eliminate the income smoothing and timely loss recognition (Gebhardt dan Novotny-Farkas 2011), improving comparability (Brochet et al., 2013) and improvement of corporate governance (Verriest et al., 2011). The economic benefits subject to IFRS adoption are market liquidity and cost of capital efficiency (Daske et al., 2008). Moreover, studies concerning IFRS adoption benefits toward accounting quality have been conducted. Some of the benefits are increasing accounting quality (Barth et al., 2007), decreasing of income smoothing (Gebhardt and Novotny-Farkas 2011), promoting investment efficiency (Biddle et al., 2011), and improving the market's intermediating function (Horton et al., 2008). In contrast, non value added results also found as the IFRS adoption, no improvement of information's value relevance (Negash (2007) in Negash (2008)) and decreasing earning quality (Kabir et al., 2010).

Financial reports are important informations sources to investors in evaluating the corporate's performance and value. The studies also conducted to assess the relevance of accounting information attributes in evaluating corporate are performance and value through financial statement analysis. It was initiated by Ball dan Brown (1968), which was indiced that earning and its aspects were related to share price. Rahmawati (2005) found relationship between earning information and cash flow to share price. Ibrahim et al. (2009), Ayed and Abaoud (2006) conclude that earning number and its components have important role in assessing the corporate's value. Otherwise, Lopes (2002) argued that book value of equity has 
higher value relevance than earning component in assessing the market value of the company.

The IFRS convergence is expected to promote the enhancement of accounting standard, as well as the financial statement's quality. Several studies have been conducted to explore the usefulness of accounting information as relevant information to assess the companies' market value. The improvement of accounting information's value relevance after the IFRS convergention found by Li and Park (2011) in China and Devalle et al. (2010) in UK. However other researches found that there was no change in value relevance after the convergence (Konstantinos and Athanasios 2011 in Greece). Moreover, GAAP has higher value relevance than IFRS (Schiebel 2006 in German; Jarva and Lantto 2011 in Finland). The researches concerning IFRS convergence impact found various and contradictive results. The various results may be led by different method which was employed to measure the market reaction toward financial information. Hence this research is designed to investigate the market reaction around the financial report announcement, which is anticipated by information content test using event study. In addition to have comprehensive picture of the Indonesian gradual convergence, the value relevance is analysed on yearly basis.

Based on the explanation, the research problem of accounting information's value relevance before and after the IFRS convergence is relevant to be studied. The research questions are: (1) Were there any information contents on the financial statement announcement during 2005-2011?; (2) Were there any accounting information's value relevance during the years before (2005-2008) and after (20092011) the implementation of converged accounting standard?; (3) Were there any improvements of accounting information's value relevance along with the gradual implementation of converged accounting standards?

This research is conducted to investigate the accounting information's value relevance in banking, insurance, and financing companies which are listed in Indonesian Stock Exchange. The object is chosen as the fact that the IFRS convergence is strongly impact the financial companies, particularly caused by the prospective implementation of PSAK 50 and 55 (IAS 32 and 39). Actually the impacts of IFRS convergence are contributed by many implemented standards, but PSAK 50 and 55 are recognized as the standards with strong impact as their significant accounting changes. Moreover the financial industry is recognized as the most affected ones as their high portion of financial asset/liabilities. This research is aimed to understand the accounting information's value relevance changes during the convergence years, particular in banking, insurance, and financing industry. Further analysis attempt to see how IFRS convergence works on the accounting information's value relevance of companies grouped by traded share ratio, share liquidity and affiliated country factor. Otherwise, the analysis is irrelevant to be conducted for industry-based segmentation (banking, insurance, and financing), as 
their same characteristics from the accounting standard point of view. The research's results will be usefull for the investors as considerations to employ accounting information in assessing company's performance and market value, particularly in conjunction with IFRS convergence. The results will also be usefull for standard setters in evaluating the advantages and effectiveness of Indonesian IFRS convergence.

\section{LITERATURE REVIEW AND HYPOTHESES DEVELOPMENT}

\section{Information Content on Financial Statement Announcement}

The investors would react to newly published announcement, which is considered as relevant information to estimate future cashflow. It is announcement, which has information content. The existence of information content can be tested in event study (Hartono 2009). If the financial statement announcement has information content, it will be reacted by the market as price or transaction volume changes. The price changes are measured by abnormal return, as an unusual investors reaction. Transaction volume change reflects share trading activity changes around the financial statement announcement. Before analysing the information value relevancy in the equity market, it is good to test the information content of financial statement announcement, using event study around the announcement date. Several researches found that Indonesian market reacts to financial statement announcement (Telaumbanua and Sumiyana 2008; Putra 2009). Based on the explanation, this research presumes that during the IFRS convergence, there are information contents on financial statements announcement which is observed by investors' reaction, so that the hypothesis is as follow.

H1: There are information contents subject to the announcement of financial statement.

\section{IFRS and the IFRS Convergence}

IFRS is a set of standard developed by the International Accounting Standard Board (IASB), which is prepared to be a globally used financial accounting standard. IFRS based local standards are being developed on options: adoption or convergence. IFRS adoption is simply put IFRS as local standard. While in IFRS convergence, local standards are developed to conform to the IFRS. The more convergent local standard, the easier IFRS adoption will be in the future (IFRS.com accessed May $\left.6^{\text {th }}, 2015\right)$. Indonesia's IFRS convergence is a process of eliminating differences between PSAK and IFRS. Before the convergence, Indonesian standard is based on GAAP. There will be many reconciling items to compare the IFRS and PSAK, as manifestation of fair value concept in recognizing, measuring, and disclosing the financial information. 


\section{Financial Information's Value Relevance}

Financial Information's value relevance is defined as financial statement's ability to summarize informations affecting the share value, in which the relation between market value and accounting information has been statistically proofed (Mohan and John 2011). Research to study the relationship between share value and financial information was initiated by Ball and Brown (1968). It was the earning information expediency in the investment decision research. Other financial informations, which have the value relevance, are book value of equity (Lopes 2002) and cashflow (Jiang 2009). In regard to information expediency, Lev and Zarowin (1999) found that the investors are tend to increase their needs of relevant information, quality enhancement, and timeliness reporting. Different approach in evaluating the value relevance has been proposed by Dichev (1997) through nonmarket approach, based on uncertainty of new information, which is presumed to affect the equity value.

Earning information would be relevant in investment decision, if there is a difference between actual income and expected income (Ball and Brown 1968). Investors anticipate the earning related informations provided in financial statement by predicting the expected income and share price, so they would only react to the announced statement if the actual is deviated from the expected income. Earning information has the value relevance as it affects investors' expectation to the future cashflow. Several studies support the existence of earning information's value relevance (Keener (2002) in US; Shamki (2012) in Jordan; Mohan and John (2011) in India; Seetharaman and Raj (2011) in Malaysia; and Glezakos et al. (2012) in Greek).

There are various methods to assess the firm value. One of them is analysis of equity book value combined with present value of all expected abnormal earning (Ohlson 1985), so that equity book value can be referred in investment decision. This conclusion is supported by Lopes (2002), Keener (2001) and Glezakos et al (2012).

Cashflow information often considered as more relevant in evaluating company's performance, as it free from accrual method manipulation and accounting bias (Lev and Zarowin 1999). Operating cashflow often employed in value relevance research as it represents cash producing ability from the main business. Several studies supporting the idea is Kwon (2009), Jiang (2009) and Barth et al. (2009).

\section{Value Relevance and IFRS Convergence}

IFRS convergence will change the financial accounting standards as well as the conceptual frameworks. IFRS concept, which promotes the enhancement of quality, comparability, and accounting information's relevance, is fair value as the basis of financial items measurement. Other IFRS important main concept is the design of principle based standard instead of rule based standard. 
Fair value represents asset's value accepted to be exchanged, liability to be settled, and equity to be exchanged between parties involved in arm's length transactions (IASB 2004). Previous Indonesian accounting standard measures financial item using historical cost approach, which is lack of reliability in measuring the real economic value. Fair value accounting benefits are improvement of information accuracy and elimination of earning management possibility (Lefebvre et al., 2009). Fair value accounting is a better method to explain the impact of economic condition and its volatility toward company's business cycle. This superiority is expected to improve the information's value relevance, so that the investment decision can be made based on qualified information. Fair value accounting is able to reduce the possibility of accounting practice that is likely to be an earning management trick. Fair value accounting produce more relevant information than historical cost do, as the historical cost approach does not able to provide asset appreciation/depreciation information (Shortridge et al., 2006). Fair value concept in IFRS is applied to measure asset cost, cost allocation to affiliated parties, assets \& liabilities revaluation, and assets impairment test (Cairns 2006).

IFRS convergence into local standard (PSAK) changes accounting standard's design. In the convergence process, there are 21 industry specific standards to be retired. The principle based standard improves the comparability of financial statements, so that more relevant in the decision making process.

Several researches have been conducted to assess the impact of IFRS toward expediency and quality of accounting information. They provide the inconclusive results. Some researches find value relevance improvement on IFRS based financial statement (Capkun et al., 2008; Devalle et al., 2010; Li and Park 2011). Otherwise, several studies found no value relevance improvement subject to IFRS adoption (Schiebel 2006; Jarva and Lantto 2011).

IFRS convergence into Indonesian local standard aimed to produce financial statement that is substantially conform with the IFRS. It is expected that the IFRS conceptual famework expediency can affect the value relevance of produced financial statement. Based on the logic, the research hypotheses are as follow.

H2a: There was value relevance of accounting information, during the convergence of IFRS into local standard (PSAK).

H2b: There was improvement of accounting information's value relevance along with the gradual IFRS convergence.

\section{Value Relevance and Traded Share Ratio}

Li and Park research (2011) found value relevance difference between companies grouped by traded share ratio. It is logical that higher traded share ratio, will make more investors look for the company's information, so that those companies will have higer value relevance. The research concluded that higher 
equity relevance found in low traded share ratio, otherwise higher earning relevance found in higher traded share ratio. Before the IFRS adoption, there is value relevance difference between high and low traded share companies, but it could not be demonstrated in period after the adoption. Based on the research findings and the explanation, the hypothesis is as follow.

H3: There are improvements of accounting informations' value relevance along with gradual IFRS convergence on banking, insurance, and financing companies, which stratified by traded share ratio.

\section{Value Relevance and Share Trading Liquidity}

This research tries to employ new variable. It is trading liquidity, as the logic that the accounting information will be more useful to contribute the market pricing on liquid share, due to more parties need the information for their decision. Based on the logic, the hypothesis is as follow.

H4: There are improvement of accounting information's value relevance along with gradual implementation of IFRS converged standard on banking, insurance, and financing companies which stratified by their share liquidity.

\section{Value Relevance and Affiliation Country Origin Factor for Foreign Ownership Companies}

Other new variable that will be tested is affiliation country origin for foreign ownership companies. IFRS implementation to financial statement requires human resources, knowledge and technology, as the implementation will change the business process. In such condition, the company (in global context) that owned IFRS implementation experience is expected to get higher success probability in implementing the converged standard. In this research context, the experienced companies refer to companies affiliated with parties from IFRS countries. Those companies can get the benefit of resource sharing related to IFRS implementation. Based on the explanation, the hypothesis is as follow.

H5: There are improvement of accounting information's value relevance along with gradual implementation of IFRS converged standard on banking, insurance, and financing companies which stratified by their affiliation with IFRS/Non IFRS country.

\section{RESEARCH METHOD}

This study is conducted as quantitative descriptive research to examine accounting information's value relevance of banking, insurance, and financing companies listed in Indonesian Stock Exhange, during the convergence period (2005- 
2011). The samples are derived using purposive method, picking out the listed companies which have complete data.

\section{Operational Definitions and Variables Measurement}

Variables used in this research are as follow.

a. Information content around the financial statement announcement date (event study).

The existence of information contents is being tested using event study. Market reactions are being measured using returns or abnormal returns, through investigating the variability of abnormal return difference around the event date. Abnormal return is the excess of actual return from the expected return. Moreover, the transaction volume activity can also be employed to measure the market reaction to the event, in which the information content can be indiced through securities' trading volume activity change. Trading volume activity is count of traded share relative to whole issued share.

b. Value Relevance of Accounting Information.

The value relevance of accounting information used in this research is the explanatory power of independent variables (earning, equity book value, and operating cash flow) toward share price. Earning, equity book value, and operating cash flow are the financial statement's components used to measure the value relevance, as several research proofed the relation of those components to the share price (Ball dan Brown 1968; Lopes 2002; Barth et al., 2009). Value relevance is proxied by determination coefficient $\left(R^{2}\right)$ of regression function modelled as linear or non linear function of following variables:

1. Price per share (dependent variable)

Price per share represents market value of company's equity. The price data used in this research is closing price as the equilibrium of supply and demand, during several window period to anticipate the investors' response variability $(\mathrm{T}+/-1,+/-2,+/-3,+/-4,+/-5)$.

2. Earning per share (independent variable)

Earning per share $=\frac{\text { Net Income }}{\text { Number of Issued Shares }}$

3. Book value per share (independent variable)

Book value per share $=\frac{\text { Equity Book Value }}{\text { Number of Issued Shares }}$

4. Operating cash flow per share (independent variable)

Operating cash flow per share $=\frac{\text { Total Operating Cash Flow }}{\text { Number of Issued Shares }}$ 
c. Traded share ratio.

Traded share ratio $=\frac{\text { Number of company's shares traded in the stock exchange }}{\text { Number of issued shares }}$

Li and Park (2011) grouped the companies based on the traded share ratio. The company with above $65 \%$ traded shares considered as high tradable ratio, otherwise low tradable ratio.

d. Share trading liquidity.

This research recognizes the share liquidity using shortlist of most liquid share in the exchange as in published in Kompas 100. It is the list of 100 most active stocks in Indonesia Stock Exchange.

e. Affiliation company origin of foreign ownership company.

The samples are grouped as the existence of ownership of affiliation from the countries adopting the IFRS.

\section{Analysis Steps}

1. Event study of information content around the financial statement announcement.

The event study is conducted to test the existence of information content attributed to financial statement announcement. The event study employs the variability of abnormal return and trading volume activity as the indicator, explained as follow (Zaqi 2006):

a. Variability of Abnormal Return (VAR)

- Calculate the share abnormal return $\mathrm{AR}_{\mathrm{it}}=\mathrm{R}_{\mathrm{it}}-\mathrm{E}\left(\mathrm{R}_{\mathrm{it}}\right)$

$\mathrm{AR}_{\mathrm{it}} \quad=$ abnormal return of stock $\mathrm{i}$ on day $\mathrm{t}$

$\mathrm{R}_{\mathrm{it}} \quad=$ actual return of stock $\mathrm{i}$ on day $\mathrm{t}$

$\mathrm{E}\left(\mathrm{R}_{\mathrm{it}}\right) \quad=$ expected return of stock $\mathrm{i}$ on day $\mathrm{t}$

Actual return of stock i on day $\mathrm{t}\left(\mathrm{R}_{\mathrm{it}}\right)$ is formulated as :

$\mathrm{R}_{\mathrm{it}}=\frac{P_{i t}-P_{i t-1}}{P_{i t-1}}$

$\mathrm{P}_{\text {it }} \quad=$ stock i price on day $\mathrm{t}$

$\mathrm{P}_{\mathrm{it}-1} \quad=$ stock $\mathrm{i}$ price on day $\mathrm{t}-1$

While $\mathrm{E}\left(\mathrm{R}_{\mathrm{it}}\right)$ is calculated using Single-Index Market Model, as follow:

$\mathrm{E}\left(\mathrm{R}_{\mathrm{it}}\right)=\alpha_{\mathrm{i}}+\beta_{\mathrm{i}} * \mathrm{Rm}_{\mathrm{t}}$

The $\mathrm{Rm}_{\mathrm{t}}$ (market retun on day $\mathrm{t}$ ) is formulated as :

$\mathrm{Rm}_{\mathrm{t}}=\frac{P m_{t}-P m_{t-1}}{P m_{t-1}}$

$\mathrm{Pm}_{\mathrm{t}} \quad=$ Composite Index on day $\mathrm{t}$

$\mathrm{Pm}_{\mathrm{t}-1} \quad=$ Composite Index on day $\mathrm{t}-1$ 
Coefficient of $\alpha$ dan $\beta$ is derived from regression function between stock return $\left(\mathrm{R}_{\mathrm{it}}\right)$ and market return $\left(\mathrm{Rm}_{\mathrm{t}}\right)$ during the estimated period. Expected return for the specific stock can be calculated using the $\alpha$ and $\beta$ coeficien.

- Calculate the Security Return Variability (SRV)

$\mathrm{SRV}_{\mathrm{it}}=\frac{\left(A R_{i t}\right)^{2}}{V(A R)_{i t}}$

SRVi,t $=$ variability of stock i's return level on day $\mathrm{t}$

ARi,t $=$ abnormal returnof stock $\mathrm{i}$ on day $\mathrm{t}$

$\mathrm{V}(\mathrm{ARi})=$ variant of stock i's abnormal return during the estimation period

Event window of this research is $\mathrm{T}-5$ until $\mathrm{T}+5$.

- Perform the paired difference test for several event window possibilities $(\mathrm{T}+/-1,+/-2,+/-3,+/-4,+/-5)$. If there is a statistical difference of average SRV, it can be concluded that there is information content attributed to financial statement announcement, which affect the market behavior.

b. Trading Volume Activity (TVA)

- Calculate the Trading Volume Activity (TVA)

$\mathrm{TVA}_{\mathrm{t}}=\frac{\sum \text { company's } \text { i share traded on day } t}{\sum \text { company's } i \text { share listed on day } t}$

- Perform the paired difference test for several event window possibilities $(\mathrm{T}+/-1,+/-2,+/-3,+/-4,+/-5)$. If there is a statistical difference of average $\mathrm{SRV}$, it can be concluded that there is information content attributed to financial statement announcement, which affect the market behavior.

The presence or absence of information content attributed to financial statement announcement determine whether the financial informations are considered by the investors in the investment decision making around the announcement date. Then the next step is calculating the accounting information's value relevance for each observed year.

2. Calculation of accounting information's value relevance for each observed year

Value relevance calculation is based on Ohlson's (1995) equation, combined with additional variable of operating cash flow. The value relevance is measured as independent variable's determination coefficient or the power of each independent variable (book value of equity, earning, operating cash flow) to influence the share price. The determination coefficients of regression function for each observed year are being calculated using following equation: 


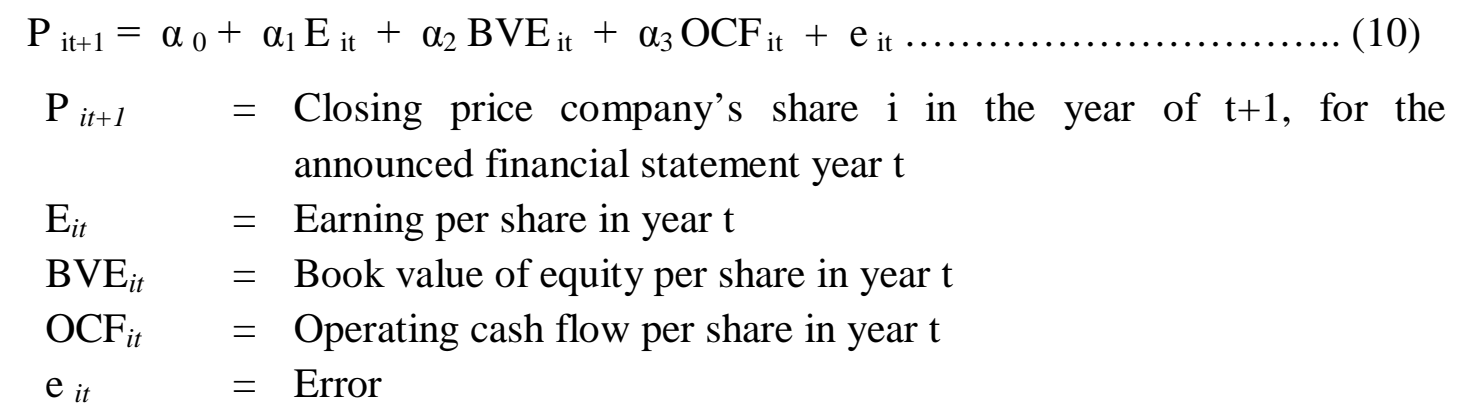

3. Trend analysis of value relevance during the IFRS convergence period.

The trends of value relevance during convergence period are analyzed to examine the behavior of value relevance for theperiod before the IFRS convergence until the convergence period. The analysis helps to determine whether the IFRS convergence is being followed by the value relevance growth.

\section{RESULT AND DISCUSSION}

\section{Result}

The research employs 337 firm years as the samples, which are the data of banking, insurance, and financing companies listed on Indonesia Stock Exchange during 2005-2011.

Table 1

Research Object

\begin{tabular}{lccccccc}
\hline \multicolumn{1}{c}{ Industry } & $\mathbf{2 0 0 5}$ & $\mathbf{2 0 0 6}$ & $\mathbf{2 0 0 7}$ & $\mathbf{2 0 0 8}$ & $\mathbf{2 0 0 9}$ & $\mathbf{2 0 1 0}$ & $\mathbf{2 0 1 1}$ \\
\hline Banking & 22 & 24 & 26 & 27 & 29 & 31 & 31 \\
Insurance & 10 & 10 & 10 & 10 & 10 & 10 & 10 \\
Financing & 9 & 9 & 11 & 11 & 11 & 12 & 14 \\
\hline \multirow{2}{*}{ Total } & $\mathbf{4 1}$ & $\mathbf{4 3}$ & $\mathbf{4 7}$ & $\mathbf{4 8}$ & $\mathbf{5 0}$ & $\mathbf{5 3}$ & $\mathbf{5 5}$ \\
\cline { 2 - 7 } & & & $\mathbf{3 3 7}$ &
\end{tabular}

Source: research data

\section{Descriptive Statistics}

During IFRS convergence period, book value of equity per share averages are between Rp575 - Rp987, earning per share averages are between Rp68 - Rp150, while the operating cashflow averages are between $\mathrm{Rp}(214)$ - Rp37. The traded share ratio averages are on the range of 66 percent - 92 percent. Moreover, around 15 percent - 20 percent samples have liquid traded shares, and around 11 percent - 17 percent have affiliation originated from IFRS adopting countries. 
Table 2

Descriptive Statistics

\begin{tabular}{|c|c|c|c|c|c|c|c|}
\hline Year & 2005 & 2006 & 2007 & 2008 & 2009 & 2010 & 2011 \\
\hline \multicolumn{8}{|c|}{ Book value of equity per share (Rp.) } \\
\hline Min & 16 & 18 & 21 & 38 & (55) & $(607)$ & (138) \\
\hline Average & 9.938 & 575 & 617 & 671 & 702 & 824 & 987 \\
\hline Max & 383.435 & 2.427 & 3.595 & 3.946 & 3.223 & 4.630 & 8.497 \\
\hline Std. Deviation & 59.792 & 560 & 715 & 756 & 743 & 1.047 & 1.455 \\
\hline \multicolumn{8}{|c|}{ Earning per share (Rp.) } \\
\hline Min & $(30)$ & (17) & $(121)$ & (37) & $(158)$ & (15) & $(125)$ \\
\hline Average & 2.247 & 72 & 77 & 97 & 108 & 150 & 138 \\
\hline Max & 89.428 & 464 & 560 & 1.020 & 1.212 & 1.468 & 1.581 \\
\hline Std. Deviation & 13.956 & 110 & 137 & 177 & 207 & 259 & 251 \\
\hline \multicolumn{8}{|c|}{ Operating Cash Flow per Share (Rp.) } \\
\hline Min & $(275.195)$ & (935) & $(1.821)$ & (3.519) & $(1.548)$ & $(9.505)$ & (9.907) \\
\hline Average & (6.676) & 188 & (8) & (188) & (20) & (54) & $(214)$ \\
\hline Max & 1.785 & 3.429 & 1.947 & 835 & 1.772 & 3.771 & 1.816 \\
\hline Std. Deviation & 42.988 & 641 & 522 & 802 & 489 & 1.498 & 1.450 \\
\hline \multicolumn{8}{|c|}{ Liquid / Not Liquid Share (\%) } \\
\hline Liquid & $17 \%$ & $18 \%$ & $20 \%$ & $16 \%$ & $17 \%$ & $18 \%$ & $15 \%$ \\
\hline Not Liquid & $83 \%$ & $82 \%$ & $80 \%$ & $84 \%$ & $83 \%$ & $82 \%$ & $85 \%$ \\
\hline \multicolumn{8}{|c|}{ Affiliation to IFRS Country } \\
\hline Affiliated & $11 \%$ & $11 \%$ & $12 \%$ & $15 \%$ & $15 \%$ & $16 \%$ & $17 \%$ \\
\hline Not Affiliated & $89 \%$ & $89 \%$ & $88 \%$ & $85 \%$ & $85 \%$ & $84 \%$ & $83 \%$ \\
\hline \multicolumn{8}{|c|}{ Traded Shares Ratio } \\
\hline Min & $30 \%$ & $0,24 \%$ & $0,24 \%$ & $0,24 \%$ & $0,004 \%$ & $0,004 \%$ & $0,004 \%$ \\
\hline Average & $91,86 \%$ & $92,75 \%$ & $90,57 \%$ & $87,58 \%$ & $80,44 \%$ & $76,27 \%$ & $66,88 \%$ \\
\hline Max & $100 \%$ & $100 \%$ & $100 \%$ & $100 \%$ & $100 \%$ & $100 \%$ & $100 \%$ \\
\hline Std. Deviation & $18 \%$ & $18 \%$ & $23 \%$ & $23 \%$ & $28 \%$ & $28 \%$ & $32 \%$ \\
\hline
\end{tabular}

Source: calculated secondary data

Information content around the announcement of financial statement (event study)

As the statistics test results using TVA, there are information contents on the event of financial statements announcements during 2005-2011 (using confidence level of 5 percent - 10 percent). Using VAR, the information content are only presence in 2008 and 2010. These findings showed that there are market reactions to the event of financial statement announcement during 2005-2011. 
Table 3

Summary of SPSS Output for Paired Samples Difference Test Using VAR and TVA

\begin{tabular}{|c|c|c|c|c|c|c|c|}
\hline & \multicolumn{7}{|c|}{ P Value } \\
\hline & 2005 & 2006 & 2007 & 2008 & 2009 & 2010 & 2011 \\
\hline \multicolumn{8}{|c|}{ Panel A : VAR } \\
\hline $\mathrm{T}+/-1$ & 0.511 & 1 & 0.880 & 1 & 0.775 & 1 & 0.892 \\
\hline $\mathrm{T}+/-2$ & 0.907 & 0.910 & 0.915 & 0.576 & 0.762 & 0.624 & 0.923 \\
\hline $\mathrm{T}+/-3$ & 0.849 & 0.579 & 0.542 & 0.235 & 0.869 & 0.378 & 0.814 \\
\hline $\mathrm{T}+/-4$ & 0.681 & 0.378 & 0.327 & $0.093 * *$ & 0.721 & $0.091 * *$ & 0.454 \\
\hline $\mathrm{T}+/-5$ & 0.883 & 0.667 & 0.200 & 0.229 & 0.523 & $0.094 * *$ & 0.855 \\
\hline \multicolumn{8}{|c|}{ Panel B : TVA } \\
\hline $\mathrm{T}+/-1$ & 0.503 & 0.307 & 1 & 0.710 & 0.499 & 0.749 & 0.280 \\
\hline $\mathrm{T}+/-2$ & 1 & $0.002^{*}$ & 0.281 & 0.245 & $0.086 * *$ & 0.815 & $0.064 * *$ \\
\hline $\mathrm{T}+/-3$ & 1 & $0.000 *$ & $0.082 * *$ & $0.090 * *$ & $0.072 * *$ & 0.338 & $0.015^{*}$ \\
\hline $\mathrm{T}+/-4$ & 0.353 & $0.000 *$ & $0.092 * *$ & $0.034^{*}$ & $0.082 * *$ & $0.099 * *$ & $0.007^{*}$ \\
\hline $\mathrm{T}+/-5$ & $0.080 * *$ & $0.000 *$ & $0.091^{* *}$ & $0.006^{*}$ & $0.099 * *$ & $0.086^{* *}$ & $0.032 *$ \\
\hline $\begin{array}{l}\text { Source: } \\
\text { *Signifi } \\
* * \text { Signi }\end{array}$ & $\begin{array}{l}\text { culated sec } \\
\text { t on } \alpha=0 \text {. } \\
\text { nt on } \alpha=\end{array}$ & dary data & & & & & \\
\hline
\end{tabular}

\section{Discusssion}

Based on the statistical result of the event study, it is concluded that H1 is accepted that there are information contents subject to the announcement of financial statement. Based on these findings, we can go to further analysis of value relevance of accounting information during the IFRS convergence.

\section{Symultant Value Relevance of Accounting Information during the IFRS Convergence}

Statistical method employed to derive the value relevance figure on yearly basis is regression analysis, so it is required to fulfill the classic assumption test. As the test for 7 observed years, the data are free of heteroscedasticity, multicolinearity, and autocorrelation, but the normality assumption for 2007 and 2011. However the normality problems are ignored, as all the population members are used for sample.

Symultant statistical analysis result for earning, operational cashflow, and equity's value relevance as Graphic 1 . Presented data in Graphic 1 are adjusted $R^{2}$ of regression function during IFRS convergence. All of the regression function are significant at 5 percent confidence level. This result supports the hypothesis 2a, which can be concluded that there are value relevances of accounting information during IFRS convergence. Further analysis of this trend result shows that the value relevances are steady in 2005-2007, but it shows a gradual increment started in 2008 until 2011, along with the IFRS convergence. This finding is consistent with Li and Park (2011) research result that the IFRS convergence brings the expediency of value relevance improvement. 


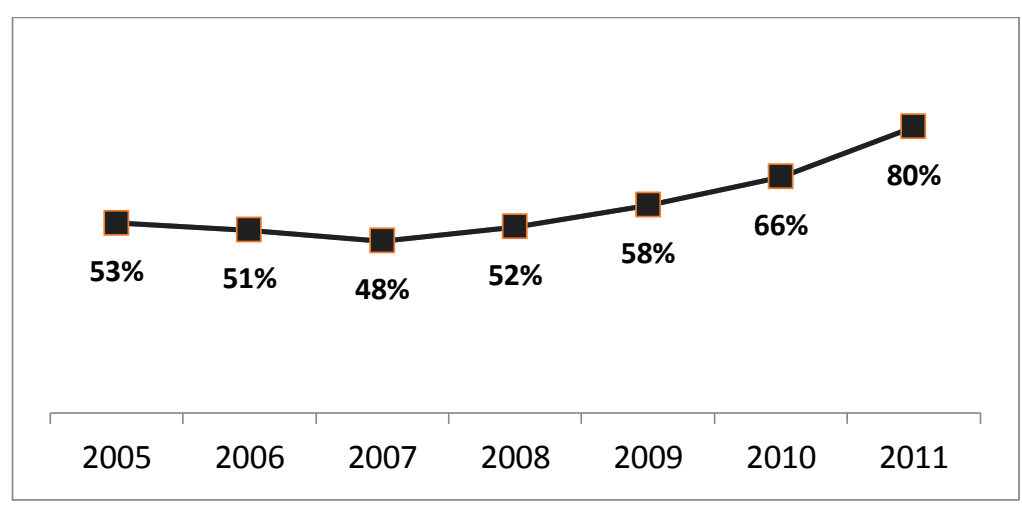

Source: calculated secondary data

Graphic 1

Value Relevance of Accounting Information during IFRS Convergce

\section{Partial Value Relevance of Earning, Equity, and Operating Cashflow}

Partial test of earning, equity and operating cashflow information's value relevance result as Graphic 2. Partial test of accounting information component shows consistent result to support the hypothesis 2a, which is the existence of value relevance for each earning, book value of equity, and operating cashflow, during the IFRS convergence. Further analysis found a supportive evidence for hypothese 2b, that earning's value relevance are improved during the convergence period. This result consistent with Capkun et al. (2008) claimed that the earning informations are more value relevance in the transition period of GAAP to IFRS in Euoropean Union. As for now, the value relevance of equity book value during the IFRS convergence are considered as stable. This evidence is tend to support previous studies that find no proof of value relevance improvement attributed to IFRS adoption (Schiebel 2006), Jarva and Lantto (2011)). However, the value relevance of operating cashflow shows a significant incremental for 2009-2011, continued from three stable years. This finding shows that market reliance to cashflow information improves during the IFRS convergence. 


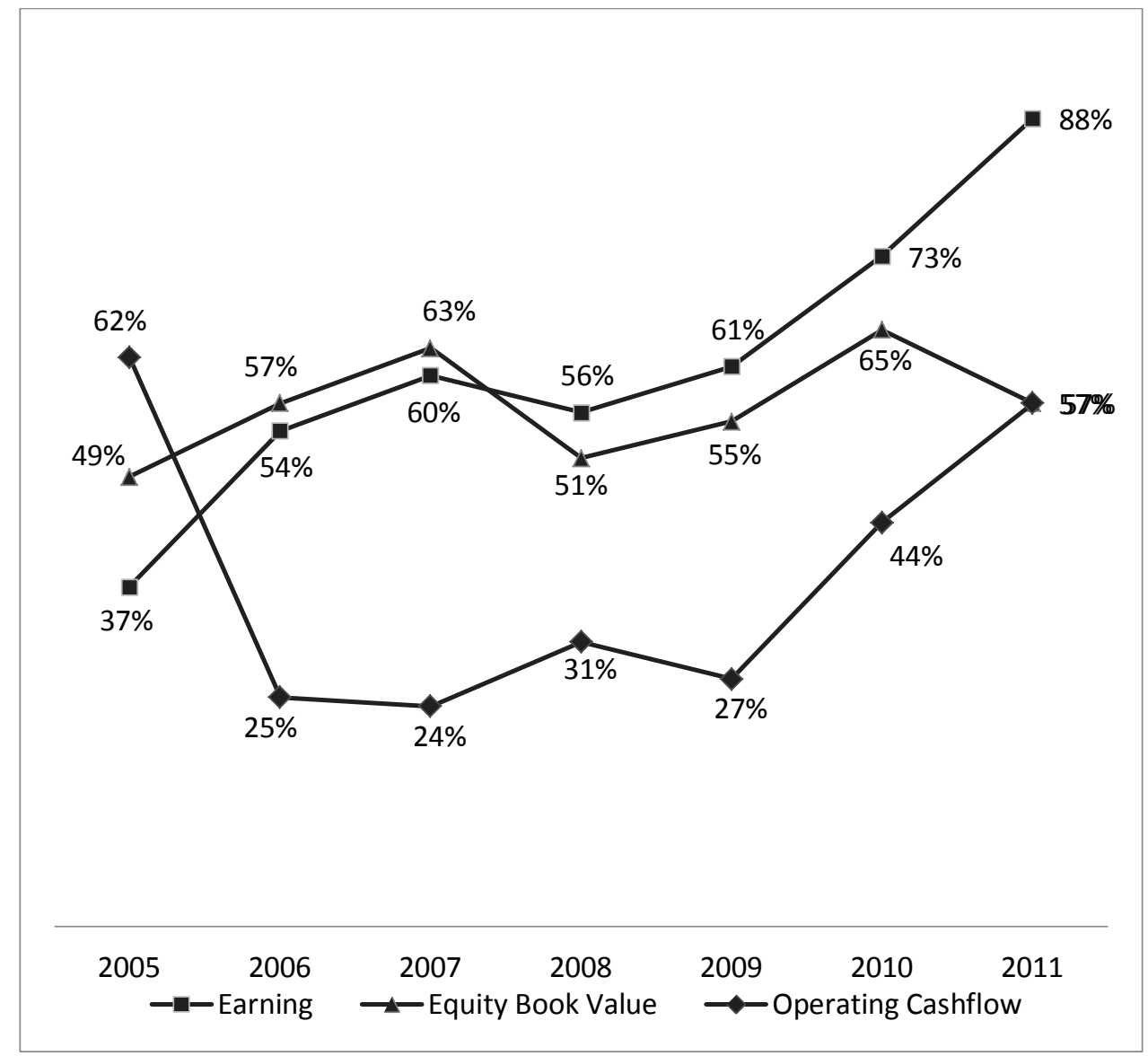

Source: calculated secondary data

\section{Graphic 2}

Partial value relevance of Earning, Equity Book Value, and Operating Cashflow during 2005-2011

\section{Value Relevance and Traded Share Ratio}

Initial step to analyze the impact of traded share ratio toward value relevance is to include the ratio as controlling variable on regression function. The regression test for the ratio as controlling variable is as follow.

\section{Table 4}

Regression Coefficient on Model Controlled by Traded Share Ratio

\begin{tabular}{cc}
\hline Year & Coefficient \\
\hline 2005 & -182.8 \\
2006 & $-1790^{*}$ \\
2007 & $-996.2^{*}$ \\
2008 & -437 \\
2009 & -569 \\
2010 & -639 \\
2011 & -424 \\
\hline
\end{tabular}

Impact of traded share ratio toward share price, which is analyzed as controlling variable shows a significant impact only in 2006 and 2008. However, if 
the variable is included as the stratification basis upon the sample, the result is as Grapic 3. The graphic presents adjusted $\mathrm{R}^{2}$ of regression functions which have been significantly proofed at 5 percent confidence level. As the stratified samples analysis, the research finds value relevance decrement over observed years on low traded share ratio companies. Otherwise, the high traded share ratio companies experience increment of value relevance, particular during IFRS convergence period. This findings support previous presumed logic, which is the more traded share ratio, the more value relevance as many parties are intend to refer the accounting information.

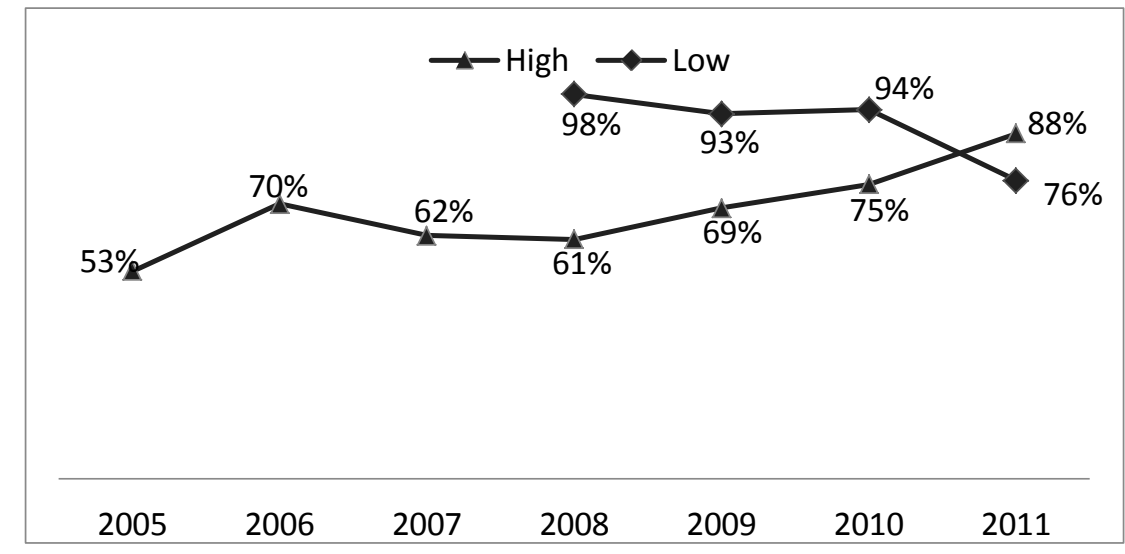

Graphic 3

Value Relevance of Accounting Information on Samples which are Stratified

Based on Traded Share Ratio

\section{Value Relevance and Share's Trading Liquidity}

Analysis of liquidity as controlling variable on the regression function results as follow.

Table 5

Regression Coefficient on Model

Controlled by Share Liquidity

\begin{tabular}{cc}
\hline Year & Coefficient \\
\hline 2005 & 233.38 \\
2006 & $624.5^{*}$ \\
2007 & $772.6^{*}$ \\
2008 & $582^{*}$ \\
2009 & $1434^{*}$ \\
2010 & $1906^{*}$ \\
2011 & $708^{*}$ \\
\hline
\end{tabular}

*significant at 5\% confidence level

Source: calculated secondary data

The liquidity as controlling variable is statistically proofed its significant impact toward share price during 2006-2011. However, if the variable is included as the stratification basis upon the sample, the result is as follow: 


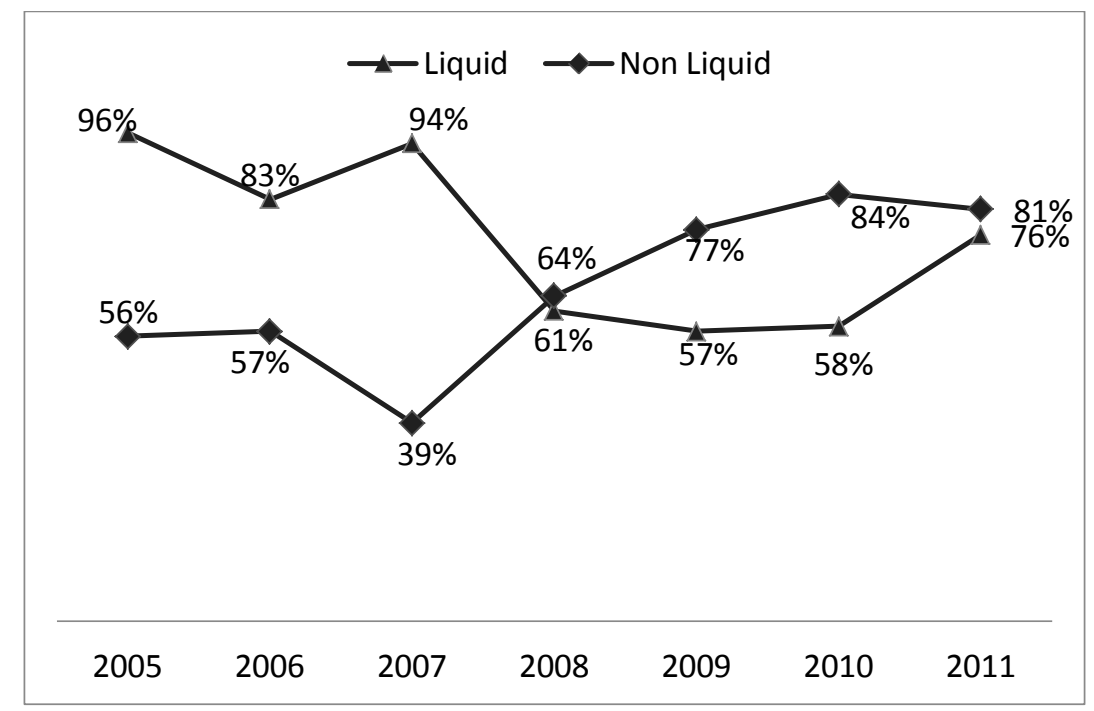

Source: calculated secondary data

Graphic 4

Value Relevance of Accounting Information on Samples which are Stratified Based on Liquidity

The graphic presents adjusted $\mathrm{R}^{2}$ of regression functions which have been significantly proofed at 5 percent and 10 percent confidence levels. As the stratified samples analysis, the research finds both groups' value relevance improve over recent years. Liquid companies experienced value relevance improvement in 20092011. Non liquid companies started to improve the value relevance in 2007. After the convergence period, non liquid companies have higher value relevance than the liquid ones. This finding does not support the presumed logic.

\section{Value Relevance and Affiliation Country Origin Factor for Foreign Ownership Companies}

Analysis to include the affiliation company origin factor as controlling variable results as follow.

Table 6

Regression Coefficient on Model

Controlled by \% Affiliation to IFRS Country

\begin{tabular}{cc}
\hline Year & Coefficient \\
\hline 2005 & -245.5 \\
2006 & $-878.4^{*}$ \\
2007 & -1.084 \\
2008 & 32 \\
2009 & -370 \\
2010 & -202 \\
2011 & 359 \\
\hline
\end{tabular}

*significant at $5 \%$ of confidence level

Source: calculated secondary data 
Affiliation country origin factor are significant only in 2006 and 2007. However, if the variable is included as the stratification basis upon the sample, the result is as follow:

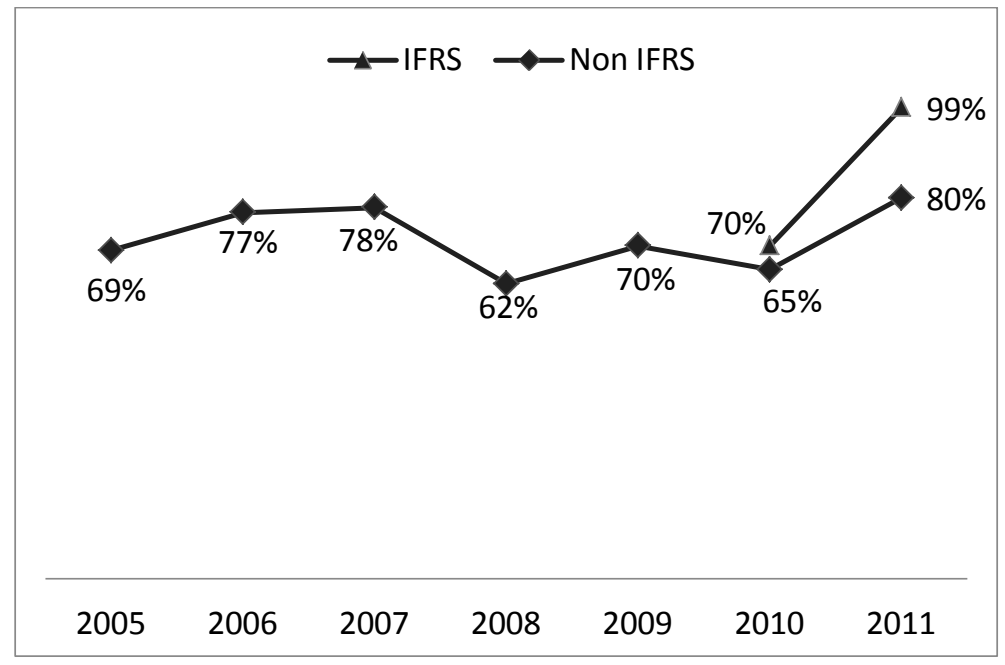

Graphic 5

Value Relevance of Accounting Information on Samples which are Stratified Based on Affiliation Country Origin

The graphic presents adjusted $\mathrm{R}^{2}$ of regression functions which have been significantly proofed at 5 percent and 10 percent confidence levels. This research finds that companies, which are affiliated to IFRS country, have higher value relevance than those are not. The IFRS affiliated companies also experience significant increase of value relevance from the year of 2010 to 2011. However, the other group experienced value relevance growth from 2008, even if lower than IFRS affiliated companies. This finding support the presumed logic that IFRS affiliated companies has superiority in implementing the IFRS, so that the accounting products are more value relevance.

\section{CONCLUSION AND LIMITATION}

As the test conducted, this research concludes that there are market reactions toward financial statement announcement during 2005-2011, which are reacted by trading volume changes. However, abnormal return changes as the market reactions are present only in 2008 and 2010. Based on the findings, it is concluded that the announced financial informations have information content in share price determination, and then the next analysis is on accounting information's value relevance.

This research finds that during 2005-2011, the three accounting informations (earning, equity book value, and operating cashflow) are simultaneously impact the share price, in other words: there are value relevances of accounting informations. 
Further analysis concludes that the value relevances are stable during 2005-2008, but they were gradually improved during 2009-2011 along with the IFRS convergence progress. As the partial analysis, it concludes consistent results. The information components are partially affecting the share price. Further analysis found that the earning and cashflow's value relevance increase in accordance with IFRS convergence, but the equity book value are stable.

The analysis on high traded share ratio companies finds that the value relevance is increase along with the IFRS convergence; otherwise it is decreasing on low traded share companies. Companies with liquid shares experienced significant increment of value relevance in 2011; otherwise the non liquid companies increased their value relevance from 2007. Companies affiliated with IFRS countries have higher value relevance, which were increased in 2010-2011; otherwise the other group members experienced stable value relevance over years.

This research concludes that Indonesian market responses the IFRS based accounting information. The findings can be used as the input to Indonesian Institute of Accountants to evaluate the progress of IFRS convergence, to anticipate strategies particular in regard to the socialication, convergence implementation, and future adoption.

The limitation of this research is not considering the economic benefit of IFRS convergence to Indonesia. Further research may regard this consideration by examining the international capital inflow and other economic indicators.

\section{REFERENCES}

AICPA. 2011. International Financial reporting Standards-An AICPA Backgrounder. American Institute of Certified Public Accountants. Available at $h t t p: / / w w w . i f r s . c o m$.

AICPA. 2012. International Financial Reporting Standards. Available at http://www.ifrs.com.

Ayed, M. R. B., and E. Abaoub. 2006. Value relevance of accounting earnings and the information content of its components: Empirical evidence in Tunisian Stock Exchange. Available at http://papers.ssrn.com.

Ball, R., and P. Brown. 1968. An empirical evaluation of accounting income numbers. Available at www.chicagobooth.edu.

Barth, M. R. B., W. H. Hand, J. M. Landsman, and W. R. Landsman. 1999. Accruals, cash flows, and equity values. Review of Accounting Studies. Vol.4 No.3.

Barth, M. E., W. R. Landsman, and M. H. Lang. 2007. International accounting standards and accounting quality. Journal of Accounting Research. Vo.39: 467-498. 
Biddle, G. C., C. M. Callahan, H. A. Hong, and R. L. Knowles. 2011. Does mandatory adoption of international financial reporting standards increase investment efficiency?. Available at leeds.colorado.edu.

Broche, F., A. Jagolinzer, and E. J. Riedl. 2013. Mandatory IFRS adoption and financial statement comparability. Contemporary Accounting Research. Vol.30 No.4.

Cairns, D. 2006. The use of fair value in IFRS. Accounting in Europe. Vol.3.

Capkun, V., A. Cazavan-Jeny, T. Jeanjean, and L. A. Weiss. 2008. Earnings management and value relevance during the mandatory transition from Local GAAPs to IFRS in europe. Available at http://papers.ssrn.com.

Daske, H., L. Hail, C. Leuz, and R. Verdi. 2008. Mandatory IFRS reporting around the world: Early evidence on the economic consequences. Journal of Accounting Researh. Available at http://ssrn.com.

Devalle, A., E. Onali, and R. Magarini. 2010. Assessing the value relevance of accounting data after the introduction of IFRS in europe. Journal of International Financial Management and Accounting Vo.21 No.2.

Dichev, I. 1997. Measuring value-relevance in accounting-based variables without reference to market price. Available at http://papers.ssrn.com.

Gebhardt, G., and N. F. Zoltan. 2011. Mandatory IFRS adoption and accounting quality of european banks. Journal of Business Finance and Accounting Vol.38 No.3: 289-333.

Glezakos, M., J. Mylonakis, and C. Kafouros. 2012. The impact of accounting information on stock prices: Evidence from the athens stock exchange. International Journal of Economics and Finance. Vol.4 No.2.

Hartono, J. 2009. Teori Portofolio dan Manajemen Investasi. Edisi Keenam. Yogyakarta: BPFE.

Horton, J., G. Serafeim, and S. Ioanna. 2010. Does mandatory IFRS adoption improve the information environment? Harvard Business School Working Paper. Available at http://papers.ssrn.com.

How widespread is the adoption of IFRS around the world?Available at www.ifrs.com.

IASB. 2004. IFRS 2 Appendix A. Available at ec-europa.eu.

Ibrahim, M. B. A., H. F. B. Bujang, N. Madi, A. B. A. Samah, U. S. B. Ismai, K. Jusoff, and A. Narawi. 2009. Value-relevance of accounting numbers for valuation. Journal of Modern Accounting and Auditing. Vol.5 No.9: 30-39.

IFRS. IFRS FAQs. Available at http://www.ifrs.com. 
Jarva, H., and A. M. Lantto. 2011. Information content of IFRS versus domestic accounting standards: evidence from Finland. Availanle at http://ssrn.com.

Jiang, B. 2009. An empirical study on information content of accounting earnings and cash flow. Journal of Modern Accounting and Auditing. Vol.5 No.7.

Kabir, M. H., F. Laswad, and M. A. Islam. 2010. Impact of IFRS in New Zealand on accounts and earnings quality. Australian Accounting Review No.55 Vol. 20: 343-357.

Keener, M. H. 2001. The relative value relevance of earnings and book value across industries. Journal of Finance and Accountancy. Vol.6: 1-19.

Konstantinos, P. P., and B. P. Athanasios. 2011. The value relevance of accounting information under greek and international financial reporting standards: the influence of firm-specific characteristics. International Research Journal of Finance and Economics. Vol.76. Available at http://ssrn.com.

Kwon, G. J. 2009. The value relevance of book values, earnings and cash flows: evidence from Korea. International Journal of Business and Management. Vol.4 No.10.

Lefebvre, R., E. Simonova, and M. Scarlat. 2009. Fair value accounting: the road to be most travelled. Issue In Focus of Certified General Accountants of Canada.

Lev, B., and P. Zarowin. 1999. The boundaries of financial reporting and how to extent them. Journal of Accounting Research. Vol.37 No.2. Available at ebsco.com.

Li, J., and S. Y. Park. 2011. The value relevance effects of IFRS adoption: the case of the People's Republic of China. Korea International Accounting Review. Available at www.ssrn.com.

Lopes, A. B. 2002. The value relevance of Brazilian accounting numbers: an empirical investigation. Available at http://papers.ssrn.com.

Mohan, N., and F. John. 2011. Value relevance of accounting information-an Indian perspective. Journal of Finance, Accounting and Management. Vol.2 No.1: 1-11. Available at ebsco.com.

Negash, M. 2008. The effect if IFRS adoption: a review of early evidence. Available at $h t t p: / / s s r n . c o m$.

Ohlson, J. A. 1995. Earnings, book values, and dividends in equity valuation. Contemporary Accounting Research. Vol.11 No.2.

Putra, I. S. 2009. Pengaruh pasar atas pengumuman laporan keuangan tahunan perusahaan di bursa efek jakarta. Jurnal Kompilek STIE Kesuma Negara. Vol.1 No.1 (Desember). Available at http://kompilek.stieken.ac.id. 
Rahmawati. 2005. Relevansi nilai informasi akuntansi dengan pendekatan terintegrasi: hubungan non-linier. Simposium Nasional Akuntansi VIII: 308324.

Ramanna, K., and E. Sletten. 2009. Why do countries adopt international financial reporting standards?. Working Paper-Harvard Business School. Available at http://hbswk.hbs.edu.

Schiebel, A. 2006. Value relevance of german GAAP and IFRS consolidated financial reporting: an empirical analysis on the frankfurt stock exchange. 29th Annual Congress of the European Accounting Association. Available at http://ssrn.com.

Seetharaman, A., and H. R. Raj. 2011. An empirical study on the impact of earning per share on stock prices of a listed bank in Malaysia. The International Journal of Applied Economics and Finance. Vol.5: 114-126.

Shamki, D., and A. A. Rahman. 2012. Value relevance of earnings and book value: evidence from Jordan. International Journal of Business and Management Vol.7.

Shortridge, R. T., A. Schroeder, and E. Wagoner. 2006. Fair-value accounting: analyzing the changing environment. The CPA Journal Online. Available at http://www.nysscpa.org.

Telaumbanua, B., and Sumiyana. 2008. Event study: Pengumuman laba terhadap reaksi pasar modal (Studi empiris bursa efek Indonesia 2004-2006). Jurnal Manajemen Teori dan Terapan. Vol.1 No.3. Available at isjd.pdii.lipi.go.id.

Verriest, A., A. Gaeremynck, and D. B. Thornton. 2011. The impact of corporate governance on IFRS adoption choices. European Accounting Review. Available at http://ssrn.com.

Zaqi, M. 2006. Reaksi pasar modal Indonesia terhadap peristiwa-peristiwa ekonomi dan peristiwa-peristiwa sosial-politik dalam negeri (Studi pada saham LQ45 di BEJ periode 1999-2003). Unpublished Master Thesis. Diponegoro University. 